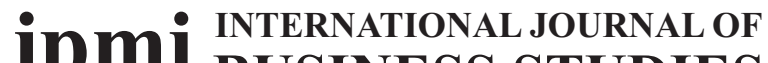 BUSINESS STUDIES
}

ISSN: 2580-0132

Vol. 1 | No. 2 (October 2017)

\section{Impact of Corporate Social Responsibility (CSR) Implementation on The Profitability of State-Owned Enterprises: An Analysis of 20 Listed Companies in Indonesia}

\author{
Febrizal Rahmana ${ }^{1^{*}}$ \\ ${ }^{1}$ Sekolah Tinggi Manajemen Ipmi, Jakarta 12750, Indonesia
}

\begin{abstract}
A B S T RA C T
The purpose of this research is to prove that State-Owned Enterprises (SOEs) that invest in CSR will optimize profit in the hope that the satisfaction of stakeholders is reached effectively. This paper is a quantitative analysis of an exploratory approach. Discusses the implementation of CSR from 20 state-owned companies is go public companies. This analysis is based on the Global Reporting Initiative report which provides some aspects of sustainability.The reports were taken from the availability both CSR and financial data.The next step is to look at the EPS trend of these SOEs and comparing to those aspects are applied. The restrictions coverage of this paper is only for 20 state-owned companies which listed in Indonesia.In this research proves that the implementation of CSR has not yet become the burden of SOEs but can also give the profit growth of those SOEs. Where there is a positive relationship between the implementation of CSR and the Earning Per Share (EPS) with coefficient correlation (R) is 0.110 , even the tendency of increasingly integrated CSR programs grow the profit of SOEs. There is the theoretical implication to management science that the implementation of CSR is not a burdening cost but is an investment and CSR is one ofmany ways for companies to increase business competitiveness in the present era. Also, there is the managerial implication that by implementation CSR is very important to have a mutual benefit between society and corporation while SOEs still can optimize some profit. This understanding is essential as a high concentration in social and corporate relations in modern times.
\end{abstract}

ART ICLE INFO

\section{Keywords:}

Corporate social responsibility, State-owned enterprises, Earning per share, Stakeholders, Sustainability.
*Correspondent Email:

febrizal.rahmana@ipmi.ac.id 


\section{INTRODUCTION}

Corporate social responsibility (CSR) has become the point of interest for business practice. For the last few decades, being profitable is not the only challenge for businesses (Carroll, 1991). The concern to the social and environmental impact of the business drives the companies to another issue: sustainability (Crosbie \& Knight, 1995).

CSR implementation as an embodiment of sustainability of the company, the company's management must have the capability in the form of reliable leadership skills to steer and drive the company in achieving its vision and mission as stated by Hiriyappa (2009: 134).

A company must have the intention to deliver a strategic role, as presented by C.W. Lin (2014) as follows: a) planning some strategies based on the vision and mission of the company; b) implementing of the strategies based on ethics, laws, and regulations; c) predicting the economic, social, environmental impacts; d) conducting multilateral cooperation, governments, NGOs, involving all of stakeholders, in implementing CSR for sustainability.

Sustainability is a concept of economic development, which places emphasis on the balance between profit, people, and the planet. Profit is related to the economic concept; people are related to the safety of people and the planet is related to the earth where sentient beings live. The concept of sustainability applied in the business world is now well known as Corporate Social Responsibility (CSR) according to Elkington (1997). Then Dentchev (2005) added that concepts of CSR have become concerns in the midst of scholar from many disciplines.

Crosbie and Knight (1995) stated socially and environmentally sustainable issues throughout of survival, competition, and development as the strategic challenge. Current time, the strategy involves socially and environmentally responsible, to present an opportunity to build a competitive advantage of businesses as believed by Lindgreen,et al. (2008) that CSR implementation would also create a competitive advantage. To gain this benefit, however, the CSR should become a comprehensive and continuous commitment. The effort includes non-economic factor integration, business differentiation, consumer and employee involvement, as well as the corporate goodwill. Therefore, that businesses can maximize their long-term returns by minimizing their negative impacts as evidenced by their voluntary reporting on CSR sustainability performance (Halabi,et al. 2006).

From the explanation above, there are previous studies as follows: As such, evidence of a relationship between strategic CSR and a firm's business success or its ability to take advantage of a good reputation for a going concern is, therefore, a significant issue for corporate management (Kotler and Lee, 2005). Refuting either of these assumptions would mean that businesses should be more cautious in investing in corporate social activities. However, proving the existence of relationships would encourage management to pursue such activities vigorously to increase shareholder value; The rationale for this study is justifiable as there is a growing perception among enterprises that sustainable business success and shareholder value cannot be achieved exclusively through maximizing short-term profits, but instead through market-oriented but also responsible behaviour (Halabi,etal. 2006).

Indonesia also takes this massive action into account. The Indonesian government, just like the governments in other nation, should be the promoter, facilitator, and mainly, the regulator of CSR (Gond, Kang, \& Moon, 2011). Consequently, in 2003, the first legal guidelines for CSR in Indonesia published. It came from the ministerial decree from the Minister of State Owned Enterprise. Obviously, the guidance was aimed to regulate the CSR practices in State Owned Enterprises (SOEs) only. The regulation for universal corporate in Indonesia is managed later, under the law number 40 the year 2007.

On this occasion, the author sees the need for further research for SOEs that also plays an 
important role in running CSR. Many firms have implemented to invest in CSR through the allocation of more resources even though other companies have resisted. The debate on whether a corporation/ should go beyond maximizing the profit of its owners as the only social responsibility of business, to being accountable for any of its actions that affect the people, communities, and environments in which they operate (Clutterbuck, et al. 1992).

To do so, this research requires both quantitative and qualitative measurement of each variable. In financial perspective, there are several ways to measure the business profitability. Global Reporting Initiatives is one of the reporting procedure commonly adopted by companies. The index assessed based on GRI would ease the measurement of the effort. Hence, this report would use Earnings Per Share (EPS) as a variable to examine its relationship to GRI indices of 20 selected Indonesia SOEs.

Therefore, the purpose of this research is to see: 1 ) corporate social responsibility can contribute to profitability; 2) CSR implementation can deliver a sustainable business.

Finally, there is the significance of research as follows: theoretically, economic science contributes in term of CSR implementationto a sustainable business for state-owned enterprises, managerially also provides inputs to the decision-makers by including CSR into the enterprise strategy to improve the performance of state-owned enterprises.

\section{LITERATURE REVIEW}

\section{Corporate Social Responsibility}

According to Fredrick (1994), at least there are three phases' evolution CSR concepts as follows: a) CSR as an examination of corporations obligation to work for social betterment as to phase 1; b) CSR as corporate social responsiveness as phase 2; c) CSR become more ethical base to managerial decision.

Cannon (1992)analyzed the development of CSR through the historical development of business involvement leading to the nature of the relationship between business, society, and government. This traditional contract between business and society has changed over the years because of the addition of new social value responsibilities placed upon business and to be included: stricter compliance with local, state, federal, and international laws; social problems; human values; health care; pollution; quality of life; equal employment opportunities; sexual harassment; elimination of poverty; child care and elderly care; support of the arts and universities; and many others. This view is reinforced by Friedman (1970) that few trends would so thoroughly undermine the very foundations of our free society as the acceptance by corporate officials of a social responsibility instead of earning a lot of money.

Generally, corporate social responsibility is how companies manage their business processes to produce an overall positive impact on society even though the implementation of corporate social responsibility among companies, as there have been different results of the responsibility to society. For instances, CSR is defined by Barclays Bank Plc through the concept of 'responsible banking'; "Responsible banking means making informed reasoned and ethical decisions about how we conduct our business, how we treat our employees and how we behave towards our customers and clients" (Barclays. 2006). In addition, Tesco Plc's CSR policy includes using their strength to deliver unbeatable value, playing their part in local communities, working with their customers to help the environment and supporting good causes (Tesco, 2006).

\section{Company and Stakeholder}

Several stakeholder concepts are as follows: Jawahar and McLaughlin (2001) stated that stakeholders like corporate citizenship value which diverted attention both managerial and scientific from stockholders standpoint to profit maximisation; Freeman (1984) mentioned that stakeholder as a firm which consists of groups has interconnection with enterprise's activities; Paya and Krauz (1995) argued that stakeholder explains 
firms as aggregation of individuals who have specific interests; and with intrinsic value is a valid normative belief in stakeholder theory (Werhane and Freeman, 1999).

From the five theories above, they agreed stakeholder is a collection of individuals who affect firm's activities with certain purposes. Therefore firm and stakeholder are dependent each other. It is impossible if there is a company does not need stakeholder and vice versa. Therefore stakeholder has significant roles, without its support and means are impossible a firm can create the profitability (Freeman and Liedtka, 1991).

For the purpose of this research, stakeholder theory delivers mindset to explain why firms involve themselves in socially responsible actions as a strategy to maximize their long-term return on investment - sustainable business success, by adopting the importance of each stakeholder group and putting this concept into the strategy of companies. Also, Dowling (2001) gave the relationships between CSR and stakeholders in a company that CSR in the context of state company is a way to connect the businesses so that allows the creation of income equitable distribution for stakeholders. There are common stakeholders such as environmentalists, government, media, NGO, supplier, financial institution, consumer, communities, employees, and suppliers.

\section{CSR and Profitability}

Several theories have been proposed to overcome the apparent incompatibility between profitability and social responsibility in Fiorina (2001), Heimann (2008) and Posoco (2013). These studies, however, go further to discuss the responsibility of businesses not only to the owners of the business but also to the individual stakeholder groups connected to the business. It is therefore important to examine the theories that determine how and why companies undertake corporate social responsibility. On this occasion, the authors give some examples of the firms that have implemented CSR with have excellent profitability, Eipstein (2008): a) Unilever, the programs bring safe drinking water to 500 million people, increasing proportion of products that meet nutritional standards, source $100 \%$ sustainable raw materials; Cemex, conducts developing and implementing environmentally sound technology, recycle and reuse the materials from cement production; Dupont, delivers the effective system of Health, Safety Environment, therefore, give back some advantages to company.

Hazlett,et al. (2007) appointed that Companies can contribute to sustainable development, the use of CSR as a strategic point of view including environmental protection and promoting social responsibility, by managing their operations in such a way as to enhance their growth and increase competitiveness. The consequence, firms should make sure all operations have sustainability values since they believe that the values would give profitability to companies.

Even though researchers have examined the relationship between social responsibility and corporate performance in the past time are important and significant. There is an important finding from earlier papers state a negative causal between CSR and financial performance because of the extra spending of investments in social responsibility. There are McGuire et al. (1988) and Aupperle,et al.(1985) described that CSR cut profitability of companies; Curran (2005) resumed the conducted research on the effects of CSRof financial performance found 10 from 34 studies are negative relationships.

From the above explanation, the researcher saw the development of the theory of CSR starting from a burden to profit company. Plus, the company should not be separated from the stakeholders. Given the way, the wheels of the company are aimed at the stakeholders. Thus there is an important relationship between the company and the stakeholders. Accordingly, the researchers found a positive relationship between CSR and profitability, this is reflected in the world-class companies that have run CSR in an integrated proven to provide significant profitability of the company. Although there are also other researchers argue that the implementation of CSR has 
a negative relationship with profitability.

\section{RESEARCH QUESTIONS}

From the explanations of introduction, literature review, there are two research questions below:

Rq1: There is an effect of CSR on earnings per share of SOEs

RQ2: There is sustainability of CSR policies of SOEs

\section{METHODOLOGY}

The research of Samy, et al. (2009) summarized Halabi, et al. (2006), "currently CSR reporting is voluntary, although with increase importance? "; The multiplicity of CSR measurement standards that exist globally poses problems for companies (Briggs and Verma, 2006) and O'Rourke (2004) states that there are several measurement standards which include Global Reporting Initiative (GRI) guidelines. On the GRI (2007) website the visionis that reporting on economic, environmental, and social performance by all organizations becomes as routine and comparable as financial reporting. GRI accomplishes this vision by developing, continually improving, and building capacity around the use of its Sustainability Reporting Framework."

The GRI is a variable used in the analysis of the relationship between CSR and financial performance. The GRI reporting guidelines are measured according to the reports on the following headings that companies describe such as(a)economic (EC), (b) environmental (EN), (c)labor practices (LA), d) human rights (HR), (e) society ( $\mathrm{SO}$ ) and(f) product responsibility (PR).

The GRI is not merely a reporting indicator but goes beyond by adopting key performance indicators and for certain sectors, it specifies core indicators. It has the principles of materiality, stakeholder inclusiveness, sustainability context, and completeness.

Then from the sustainability reporting made by the company, the GRI index is used to assess the extent to which the company implements CSR. When the company has run into the six things set by the GRI then the company has a high figure in the implementation of CSR. The highest number is 6 and the lowest is one. In this study, data from 2014 to 2016 is taken. Then from 20 SOEs that are going public seen, analyzed from sustainability reporting one by one how the level of CSR implementation of each company.The data of CSR implementation level is an independent variable which will be some input in the research.

Earnings per share (EPS) calculation is an important information for the investment community (Penman, 1992). However,Watts and Leftwich, (1977) argued that profitability is not a primary matter of investors, it is relative to their investment in the company. Bushee (1997) emphasized that EPS is a crucial indicator for both external investors and internal managerial level. EPS is utilized by investors to have forecasts regarding investment portfolios. As the internal sides, managers use EPS to predict of critical decisions such as operational budgeting, capital investments, and other resource utilization decisions. This is the easy way to use EPS as an indicator to look over company performance according to Williams (1995).

As such companies would report on CSR practices comprehensively in order to inform the stakeholders. Therefore, it is prudent for companies to ensure that they are able to meet as many indicators as possible according to the GRI.

For the purpose of this research, the dependent variable will be measured by financial performance. This research will base its measurement of business through on three years earning per share ratio (EPS) of the selected 20 SOEs. Each EPS data extracted during the previous three years is the average. Thus, those data as input as well of the study.

Both CSR level and EPS are measured by statistics as the quantitative method. Then look for indicators such as correlation coefficient, linear regression coefficient, and linear constants.

CSR data also is detected how the level of CSR implementation. Then, the trend level is analyzed 
whether running well or not. Besides, the six aspects of CSR are observed whether it still is being conducted. This measurement uses qualitative method since the research would like to know how CSR implementation is run.

All 20 companies selected for this study are listed in the IDX. Table 1 below shows the list of companies in their respective sectors.

\section{RESULTS AND DISCUSSIONS}

The CSR and EPS data retrieved historically from 2014 through 2016 comes from the ongoing reports and financial statements of each company. Information on 20 state-owned companies can be accessed through the official website of the company and the Indonesian stock exchange (IDX), this can be done because as companies go public obliged to report its activities periodically to the public. Thus, the availability of this data can be utilized in this study.
Below, the identification the data on aspects of CSR implementation of 20 SOEs going public based on GRI guidelines as follows:

From the table 2, there are two classifications based on CSR implementations: complete and not complete. The classification division is complete and incomplete based on the following explanation complete means that the company runs all six aspects from 2014 to 2016 set by GRI guidelines. While not complete means the company has not implemented from these six aspects or in the running time has decreased, not been consistent implementation during the time to time. The six aspects of CSR implementation based on GRI guidelines are Economic (EC), Environment (EN), Labor Practices (LA), Product Responsibility (PR), Human Rights (HR), Society (SO).

The companies are complete on CSR implementation as follows BBNI of bank industry,

Table 1. The 20 Listed Indonesia's SOEs

\begin{tabular}{|l|l|l|l|}
\hline \multirow{2}{*}{ No } & \multicolumn{3}{|c|}{ Company } \\
\cline { 2 - 4 } & IDX Code & \multicolumn{1}{|c|}{ Full Name } & \multicolumn{1}{c|}{ Industry } \\
\hline 1 & ADHI & PT Adhi Karya Tbk & Mining \\
\hline 2 & ANTM & PT Aneka Tambang Tbk & Banking \\
\hline 3 & BBNI & PT Bank Negara Indonesia Tbk & Banking \\
\hline 4 & BBRI & PT Bank Rakyat Indonesia Tbk & Banking \\
\hline 5 & BBTN & PT Bank Tabungan Negara Tbk & Banking \\
\hline 6 & BMRI & PT Bank Mandiri Tbk & Air Transportation, Travel, and Leisure \\
\hline 7 & GIAA & PT Garuda Indonesia Tbk & Pharmaceuticals \\
\hline 8 & INAF & PT Indofarma Tbk & Infrastructure \\
\hline 9 & JSMR & PT Jasa Marga Tbk & Pharmaceuticals \\
\hline 10 & KAEF & PT Kimia Farma Tbk & Steel Manufacture \\
\hline 11 & KRAS & PT Krakatau Steel Tbk & Gas Infrastructure \\
\hline 12 & PGAS & PT Perusahaan Gas Negara Tbk & Coal Mining \\
\hline 13 & PTBA & PT Tambang Batubara Bukit Asam Tbk & Construction \\
\hline 14 & PTPP & PT Pembangunan Perumahan Tbk & Cement Manufacture \\
\hline 15 & SMBR & PT Semen Baturaja Tbk & Cement Manufacture \\
\hline 16 & SMGR & PT Semen Indonesia Tbk & Tin Mining \\
\hline 17 & TINS & PT Timah Tbk & Telecommunication, Digital \\
\hline 18 & TLKM & PT Telekomunikasi Indonesia & Construction \\
\hline 19 & WIKA & PT Wijaya Karya Tbk & Construction \\
\hline 20 & WSKT & PT Waskita Karta Tbk & \\
\hline & & & \\
\hline
\end{tabular}


Table 2. CSR Implementation Using GRI Guidelines

\begin{tabular}{|c|c|c|c|c|c|c|c|c|c|c|}
\hline YEAR & ADHI & ANTM & BBNI & BBRI & BBTN & BMRI & GIAA & INAF & JSMR & KAEF \\
\hline 2014 & 5 & 6 & 6 & 6 & 6 & 6 & 6 & 5 & 6 & 6 \\
\hline 2015 & 5 & 6 & 6 & 6 & 6 & 6 & 5 & 5 & 6 & 6 \\
\hline 2016 & 5 & 5 & 6 & 4 & 6 & 6 & 6 & 3 & 6 & 6 \\
\hline CSR & not complete & not complete & complete & not complete & complete & complete & not complete & not complete & complete & complete \\
\hline
\end{tabular}

\begin{tabular}{|c|c|c|c|c|c|c|c|c|c|c|}
\hline YEAR & KRAS & PGAS & PTBA & PTPP & SMBR & SMGR & TINS & TLKM & WIKA & WSKT \\
\hline 2014 & 6 & 6 & 4 & 6 & 5 & 5 & 4 & 6 & 6 & 6 \\
\hline 2015 & 6 & 6 & 6 & 6 & 5 & 5 & 6 & 6 & 5 & 6 \\
\hline 2016 & 6 & 6 & 6 & 6 & 5 & 4 & 6 & 6 & 4 & 6 \\
\hline CSR & complete & complete & not complete & complete & not complete & not complete & not complete & complete & not complete & complete \\
\hline
\end{tabular}

BBTN of bank industry, BMRI of bank industry, JSMR of infrastructure industry, KAEF of the pharmaceutical industry, KRAS of steel manufacture, PGAS of gas infrastructure, PTPP of construction infrastructure, TLKM of telecommunication infrastructure and WSKT of construction infrastructure. And, which are not complete on CSR implementation ADHI of construction infrastructure, ANTM of the mining industry, BBRI of bank industry, GIAA of the transportation industry, INAF of the pharmaceutical industry, PTBA of the mining industry, SMBR of cement manufacture, SMGR of cement manufacture, TINS of mining industry, WIKA of construction infrastructure. Also, there are EPS data from 2014 to 2016 for each SOEs:

To answer RQ1, that is to examine if there is a causal relationship CSR and EPS of twenty selected Indonesian SOEs. Data was taken from both CSR and EPS as CSR implementation and EPS averages. The following data as follows:

A common statistical calculation known as product moment correlation coefficient (R) was undertaken. After calculation, there are findings that $\mathrm{R}=0.110$ with $\mathrm{n}=20$. The result of $\mathrm{R}$ from the above shows positive number, based on the SPSS calculation that If $\mathrm{R}>=0$, then a positive relationship exists. The statistical analysis clearly shows that there is a causal relationship between CSR and EPS policies. However, in analyzing the strength of the relationship, the findings indicated that it is weak. The weak relationship could be a result of the sample size of the study or the variations in the mean EPS.

To analyzeRQ2, that is to examine the extent of corporate social responsibility (CSR) policies of twenty listed SOEs. It can be referred to table 2 and table 4 . Table 2, there are two classifications SOEs as complete and not complete SOEs of CSR implementation.There are ten SOEs which complete of CSR implementation from industries: bank, infrastructure, manufacture, and pharmaceutical. Another 10 ten SOEs which are not complete of CSR implementation from industries: infrastructure, mining, pharmaceutical, manufacture, and bank. It can be seen that the only industry is not complete of CSR implementation is mining industry, as follows:

- PTBA and TINS did not apply PR and HR for 2014

- ANTM did not apply PR for 2016

Other than that, the subsequent incomplete firms carrying out aspects of defined by GRI are mentioned:

- ADHI did not implement PR for 2014 to 2016

- BBRI did not implement EN for 2016

- GIAA did not implement PR for 2015

- INAF did not implement LA and PR for 2016, HR for 214 to 2016

- SMBR did not implement HR for 2014 to 2016

- SMGR did not implement PR for 2014, HR for 2014 to 2016

- WIKA did not implement EC for 2016, HR for 2015 to 2016 
Table 3. EPS of 20 Listed SOEs, 2014 to 2016

\begin{tabular}{|c|c|c|c|c|}
\hline \multirow{2}{*}{ No } & Company & \multicolumn{3}{|c|}{ EPS } \\
\cline { 2 - 5 } & IDX Code & $\mathbf{2 0 1 4}$ & $\mathbf{2 0 1 5}$ & $\mathbf{2 0 1 6}$ \\
\hline 1 & ADHI & 182.70 & 202.80 & 88.00 \\
\hline 2 & ANTM & -77.95 & -59.96 & 2.70 \\
\hline 3 & BBNI & 578.00 & 487.00 & 610.00 \\
\hline 4 & BBRI & 981.59 & 1030.43 & 1071.51 \\
\hline 5 & BBTN & 108.00 & 175.00 & 247.00 \\
\hline 6 & BMRI & 851.66 & 871.50 & 591.71 \\
\hline 7 & GIAA & -184.05 & 40.83 & 4.17 \\
\hline 8 & INAF & 0.38 & 2.12 & -5.60 \\
\hline 9 & JSMR & 209.00 & 216.00 & 277.00 \\
\hline 10 & KAEF & 46.08 & 47.07 & 48.15 \\
\hline 11 & KRAS & -118.14 & -260.71 & -134.36 \\
\hline 12 & PGAS & 373.08 & 275.88 & 134.36 \\
\hline 13 & PTBA & 856.00 & 941.00 & 952.00 \\
\hline 14 & PTPP & 110.00 & 153.00 & 210.00 \\
\hline 15 & SMBR & 34.00 & 36.00 & 26.00 \\
\hline 16 & SMGR & 937.00 & 762.00 & 762.00 \\
\hline 17 & TINS & 90.00 & 14.00 & 34.00 \\
\hline 18 & TLKM & 148.10 & 157.80 & 196.20 \\
\hline 19 & WIKA & 99.06 & 101.81 & 158.64 \\
\hline 20 & WSKT & 51.90 & 90.19 & 147.48 \\
\hline
\end{tabular}

Table 4 shows the averages score of CSR implementation of each company with the minimum score is 1 and maximum is 6 , it can be mapped as follows:

- Ten SOEsscore is 6

- The lowest score is 4.33 for INAF

- The score of mining industry is 5.33 to 5.67

- The score of bank industry is 5.67 to 6

- Two SOEs score is around 4

- Eight SOEs score is around 5

If those analyses are reflected the theory of CSR and stakeholders on literature review, stated stakeholder delivers mindset to explain why firms involve themselves in socially responsible actions as a strategy to maximize their long-term return on investment - sustainable business success, by adopting the importance of each stakeholder group and putting this concept into strategy of companies.

The answer RQ1 and RQ2 could give confidence that CSR implementation should be included in
Table 4. CSR and EPS Averages of 20 Listed SOEs

\begin{tabular}{|c|c|c|c|}
\hline No & Company & CSR Avg & EPS Avg \\
\hline 1 & ADHI & 5,00 & 157,83 \\
\hline 2 & ANTM & 5,67 & $-45,07$ \\
\hline 3 & BBNI & 6,00 & 558,33 \\
\hline 4 & BBRI & 5,67 & 1027,84 \\
\hline 5 & BBTN & 6,00 & 176,67 \\
\hline 6 & BMRI & 6,00 & 771,62 \\
\hline 7 & GIAA & 5,67 & 22,50 \\
\hline 8 & INAF & 4,33 & $-1,03$ \\
\hline 9 & JSMR & 6,00 & 234,00 \\
\hline 10 & KAEF & 6,00 & 47,10 \\
\hline 11 & KRAS & 6,00 & $-171,07$ \\
\hline 12 & PGAS & 6,00 & 261,11 \\
\hline 13 & PTBA & 5,33 & 916,33 \\
\hline 14 & PTPP & 6,00 & 157,67 \\
\hline 15 & SMBR & 5,00 & 32,00 \\
\hline 16 & SMGR & 4,67 & 820,33 \\
\hline 17 & TINS & 5,33 & 46,00 \\
\hline 18 & TLKM & 6,00 & 167,37 \\
\hline 19 & WIKA & 5,00 & 119,84 \\
\hline 20 & WSKT & 6,00 & 96,52 \\
\hline
\end{tabular}

the business strategy to have profitability growth sustainably, besides the extent of CSR implementations of 20 listed SOEs are good enough since score higher than 3.

\section{RESEARCH LIMITATION}

This research is limited to twenty (20) listed SOEs in Indonesia Stock Exchange. They are : PT. AdhiKaryaTbk, PT. Aneka Tambang Tbk, PT. Bank Negara Indonesia Tbk, PT. Bank Rakyat Indonesia Tbk, PT. Bank Tabungan Negara Tbk, PT. Bank Mandiri Tbk, PT. Garuda Indonesia Tbk, PT. Indo farma Tbk, PT. Jasa Marga Tbk, PT. Kimia FarmaTbk, PT. Krakatau Steel Tbk, PT. Perusahaan Gas Negara Tbk, PT. Bukit Asam Tbk, PT. Pembangunan PerumahanTbk, PT. Semen Batu Raja Tbk, PT. Semen Gresik Tbk, PT. Timah Tbk, PT. Telekomunikasi Indonesia Tbk, PT. Wijaya Karya Tbk, PT. Waskita Karya Tbk.

The data were undertaken are from financial and sustainability or social responsibility reports that 
followed to the availability in the same time series among reports. The research just focused on CSR implementation from GRI point of view and profitability from EPS data year by year.

\section{CONCLUSION AND RECOMMENDATION}

Since there is a positive relationship between CSR and EPS proves that CSR implementation can contribute profitability of listed SOEs in Indonesia. This research also confirmed Eipstein (2008) that companies who implement CSR will have excellent profitability. That is why Indonesian SOEs should put CSR inside business strategies and implement it following to all aspects regulated in GRI guidelines. There are ten of twenty SOEs which have fulfilled all aspects of CSR implementation. At least already $50 \%$ listed SOEs are discipline to conduct CSR and for sure those are included in business strategies, among others : (1)PT. Bank Negara Indonesia Tbk, (2)PT. Bank Tabungan Negara Tbk, (3)PT. Bank MandiriTbk,(4)PT. JasaMargaTbk, (5)PT. Kimia FarmaTbk, (6) PT. Krakatau Steel Tbk, (7)PT. Perusahaan Gas Negara Tbk, (8)PT. Pembangunan
Peumahan, (9)PT. Telekomunikasi Indonesia Tbk, (10) PT. WaskitaKaryaTbk. Also, this study supports the previous research from Hazlett et.al (2007) appointed that companies can deliver to sustainable development by conducting CSR as environmental protection and promoting social responsibility, therefore enhancingtheir growth and increase competitiveness.

It is suggested to explore a larger data of company's reports in the future research, therefore, the data can be run over more than five years average.To have the flexibility of CSR data, it is better not only referring to sustainability report but also from some fields facts.

In addition, the next research would supposedly take a chance to dig why human rights, product responsibility aspects till are missing frequently in CSR implementation. This is important for companies and stakeholders in order to overcome the problems on the two aspects.

\section{REFERENCES}

Aupperle, W.F., Carroll, A.B. Hatfield, J.D. (1985). An empirical examination of the relationship between corporate social responsibility and profitability. Academy of ManagementJournal, 289(2), 446-463.

Baker, M. (2006). Corporate Social Responsibility, News and Resources. Retrieved from www.mallenbaker.net/csr.

Briggs, W. and Verma, A. (2006), Sharing the wealth: by giving in times of need, corporations can do good in the community - and for the bottom line. Communication World, 23(1), 25-28.

Bushee, B.J. (1997). Fundamentals analysis, future EPS, and Stock price. Journal of Accounting Research, 35(1), $1-24$.

Cannon, T. (1992). Corporate Responsibility, 1st Edition. London: Pitman Publishing.

Carroll, A. B. (1991). The pyramid of corporate social responsibility: Toward the moral management of organizational stakeholders. Business horizons, 34(4), 39-48.

Clutterbuck, D., Dearlove, D., Snow, D. (1992). Actions Speak louder: A management guide to corporate social responsibility. London: Kingfisher.

Crosbie, L., and Knight, K. (1995). Strategy for sustainable business. Environmental opportunity and strategic choice. London: McGraw- Hill.

C.W. Lin, Tom. (2014). CEOs and Presidents. United States: Temple University Beasley School of Law.

Dentchev, N. (2005). Corporate Social Performance: As Business strategy. Journal of Business Ethics, 55(4), 395-410.

Dowling, Grahame. (2001). Creating Corporate Reputations: Identity, Image, and Performance. New York: Oxford University Press. 
Eipstein, J. Marc. (2008). Making Sustainability Work. San Francisco, California: Berret-Koehler Publisher, Inc. Elkington, J. (1997). Cannibals with Forks: The Triple Bottom Line of 21st Century Business. Capstone: Oxford. Fiorina, Carly. (2001). A World of Change. Quoted from a speech to the APEC. CEO Summit in Shanghai, China. Frederick, W.C. (1994). From CSR1 to CSR2. Business and Society, 33(2), 150-66.

Freeman, R.E. (1984). Strategic management: A stakeholder approach. Boston: Pitman.

Freeman, R.E., and Liedtka, J. (1991). Corporate Social responsibility: A critical approach, Business Horizons, 34(4), 92-99.

Friedman, M. (1970). The social responsibility of business is to increase its profits. New York Times Magazine, 13.

Gond, J., Kang, N., \& Moon, J. (2011). The government of sel regulation :On the comparative dynamics of CSR. Economy and Society, 40(4), 640-671.

Halabi, A., Kazi, A., Dang, V. and Samy, M. (2006). Corporate Social Responsibility, Monash Business Review, l2(3), 22-25.

Hazlett, S.A., McAdam, R., Murray, L. (2007). From quality management to socially responsible organisations: the case for CSR. International Journal of Quality \& Reliability Management, 24(7), 669-682.

Heimann. (2008). Legitimacy of Executive Compensation Plans: A Preliminary Study of French Laypersons Acceptability. France: University of Toulouse.

Hiriyappa, B. (2009). Organizational Behaviour. New Delhi, India: New Age International (P) Limited, Publisher.

Jawahar, I and McLaughlin, (2001). Towards a descriptive stakeholder theory: An organization life cycle approach. Academy of Management Review, 26(3), 397-414.

Kotler, P., and Lee, N. (2005). Corporate social responsibility: Doing the most good for your company andyour cause. Hoboken: Wiley and Sons.

Lindgreen, A., Swaen., ohnston, W.J (2008). Corporate Social Responsibility: An Emprical of US organization. Journal Business Ethics, 85(2), 303-323.

Marina, M. C. (2005). Assessing the rate of return of the adoption of corporate social responsibility initiatives. A thesis submitted in fulfilment of the requirements for the degree of Doctor of Philosophy). University of Edinburgh.

McGuire, J.B., Sundgren, A. and Schneeweis, T. (1988). Corporate Social Responsibility and Firms Financial Performance. Academy of ManagementJournal, 31, 854-72.

O'Rourke, D. (2004). Opportunities and Obstacles in CSR Reporting in developing countries. USA: University of California

Pava M., L., Krauz. J. (1995). Corporate responsibility and Financial Performance: The paradox of social cost. London: Quorum Books.

Penman,S.H. (1992). Return to fundamentals. Journal of Accounting, Auditing \& Finance, 7(4), 465-484.

Posoco, (2013). CSR and Sustainability. 2nd E Journal on CSR \& Sustainability Activities. India.

Watts, R.L and Leftwich, R.W. (1977). The times series of annual accounting EPS (in research reports).Journal of Accounting Research, 15(2), 253-271.

Werhane, P. H., and Freeman, R.E. (1999). Business ethics: The State of Art. International Journal of Management Reviews, 1(1), 1-16.

Williams, P.A. (1995). The search for a better market expectation of earnings model. Journal of Accounting Literature, Vol. 14(1), 140-160. 